\title{
Optimising heart failure pharmacotherapy: the ideal combination
}

John G F Cleland, David P Dutka

Heart failure is a collection of syndromes, progressing at various rates and of diverse aetiology. Accordingly it is unlikely that any single agent or combination could be ideal for all cases of heart failure (table 1). Heart failure needs appropriate investigation to confirm its presence and aetiology before the best treatment can be chosen, although in acute heart failure "best guess" treatment is required initially.

Drugs are not the only way to treat heart failure. Advice on lifestyle is important. ${ }^{1}$ There is also a place for devices such as pacemakers, and for surgery for valve or coronary disease. ${ }^{1}$ The most effective treatment for severe heart failure is a transplant, although in practice this is available to only a small proportion of patients. The value of dynamic cardiomyoplasty is not yet proved. ${ }^{2}$

\section{How can the ideal combination be judged?}

There is a long tradition of assessing drugs for heart failure by their ability to reduce pulmonary capillary wedge pressure or increase cardiac output. This is no longer appropriate. Minoxidil and prostacyclin (epoprostenol sodium) are two very effective vasodilators. Minoxidil causes massive fluid retention and makes heart failure worse. ${ }^{3}$ Epoprostenol sodium makes patients feel worse ${ }^{4}$ and increases mortality.

The relation between non-invasive measurements of ventricular function and symptoms is also poor. ${ }^{5}$ Drugs that increase ejection fraction are not necessarily the most effective agents for treating heart failure. ${ }^{6}$ The finding that vasodilator as well as positive

Department of
Medicine
(Cardiology),
Hammersmith
Hospital, London
J G F Cleland
D P Dutka
Correspondence to:
Dr John G F Cleland,
Department of Medicine
(Cardiology), Hammersmith
Hospital, Du Cane Road,
London W12.

Table 1 Drugs for treating heart failure

\begin{tabular}{|c|c|c|c|}
\hline Drugs & Symptoms & Morbidity & Mortality \\
\hline ACE inhibitors & $t$ & $\downarrow \downarrow$ & $\downarrow \downarrow$ \\
\hline Diuretics & $\downarrow \downarrow \downarrow$ & 1 & \\
\hline Digoxin & & & ? \\
\hline Xamoterol & & $\uparrow \downarrow$ & $\rightarrow \uparrow$ \\
\hline Phosphodiesterase III inhibitors & $\uparrow \downarrow$ & $\uparrow$ & $\uparrow$ \\
\hline Hydralazine & $\rightarrow$ & $\rightarrow \uparrow$ & ? \\
\hline Nitrates & $\rightarrow$ & $\rightarrow \uparrow$ & $?$ \\
\hline Hydralazine and nitrates & $? \downarrow$ & $\rightarrow$ & $\downarrow$ \\
\hline Prazosin & $\uparrow$ & $\uparrow$ & $\rightarrow$ \\
\hline Nifedipine & $\uparrow$ & & $\uparrow$ \\
\hline New calcium antagonists & ? & $?$ & $?$ \\
\hline Minoxidil & $\uparrow \uparrow$ & $\uparrow$ & $?$ \\
\hline Flosequinan & $\downarrow \downarrow$ & $\uparrow$ & $\uparrow$ \\
\hline Epoprostenol sodium & $\uparrow$ & $\uparrow$ & $\uparrow$ \\
\hline Amiodarone & $\rightarrow \downarrow$ & $?$ & $?$ \\
\hline Class I antiarrhythmic & $\uparrow \uparrow$ & $\uparrow \uparrow$ & $\uparrow \uparrow$ \\
\hline$\beta$ Blockers & $\uparrow \downarrow$ & $(\downarrow)$ & $(\downarrow)$ \\
\hline Aspirin & $\rightarrow$ & & $(\uparrow \downarrow)$ \\
\hline Warfarin & $\rightarrow$ & $\downarrow \downarrow$ & $(\downarrow \downarrow)$ \\
\hline
\end{tabular}

$\uparrow$ Increase; $\rightarrow$ no change; $\downarrow$ decrease; () equivocal. inotropic agents generally do not improve and can even impair prognosis makes one question the rationale of treating chronic heart failure based on haemodynamics. Angiotensin converting enzyme (ACE) inhibitors may well effect their benefits by mechanisms other than vasodilatation. ${ }^{3}$ It is neither sufficient nor necessary for drugs to improve haemodynamics for them to be helpful for treating heart failure.

Exercise capacity has been used as a potentially objective assessment of the severity of heart failure and of the effects of treatment. In this respect it seems more successful than haemodynamic measures. Although the degree of impairment in exercise capacity, especially if supplemented by measurements of oxygen consumption, does relate to the level of symptoms, this relation is only modest, ${ }^{7}$ and agents that improve exercise capacity may have no effect or even an adverse impact on prognosis. ${ }^{89}$

Recently neuroendocrine activation has been used as a marker of the symptomatic severity of heart failure and prognosis. Increased renin-angiotensin system activity is associated with greater benefit from ACE inhibitors. ${ }^{10}$ The renin-angiotensin system is however, of little use for monitoring the effects of treatment once the patient is receiving an ACE inhibitor. Plasma noradrenaline has been mooted as an independent predictor of prognosis, but once ejection fraction is considered noradrenaline is no longer a powerful predictor. ${ }^{11} 12$ Plasma noradrenaline correlates well with simple clinical markers of the severity of heart failure such as low blood pressure and tachycardia. ${ }^{12}$ Normal elderly people have plasma noradrenaline concentrations in the same range as younger patients with heart failure. ${ }^{13}$ For these and other reasons plasma noradrenaline is of limited use. The one marker that can be useful in measuring the response to treatment is plasma concentrations of one or more of the fragments of proatrial natriuretic peptide. ${ }^{14}$ This awaits confirmation.

Thus surrogate measures have either proved misleading or are at best indirect measures of what is really important in treating heart failure; improving symptoms, reducing morbidity, improving the quality of life (a synthesis of symptoms and morbidity), and increasing longevity. Measuring meaningful outcomes needs large numbers of patients. This is not feasible for testing new drugs in their initial stages and surrogate measures will continue to be used. The least noxious 
Table 2 Treatment of heart failure

\begin{tabular}{|c|c|c|c|c|}
\hline & $\begin{array}{l}\text { First line } \\
\text { treatment }\end{array}$ & $\begin{array}{l}\text { Add on treatment } \\
\text { of choice }\end{array}$ & $\begin{array}{l}\text { Back up or } \\
\text { alternative treatment }\end{array}$ & Prophylaxis \\
\hline Asymptomatic LVSD & ACE inhibitor & & \multirow{3}{*}{$\begin{array}{l}\text { Non-ACE inhibitor vasodilator, } \\
\text { digoxin, xamoterol } \\
\text { Digoxin, } \\
\text { non-ACE inhibitor vasodilator } \\
\text { Pacemaker for } \\
\text { bradycardia }\end{array}$} & \multirow{3}{*}{$\begin{array}{l}\text { Aspirin or } \\
\text { warfarin } \\
\text { Aspirin or } \\
\text { warfarin } \\
\text { Aspirin or } \\
\text { warfarin } \\
\text { Warfarin }\end{array}$} \\
\hline Symptomatic LVSD & ACE inhibitor & Diuretic & & \\
\hline $\begin{array}{l}\text { Oedema (peripheral or } \\
\text { non-acute pulmonary) } \\
\text { Atrial fibrillation }\end{array}$ & $\begin{array}{l}\text { Diuretic } \\
\text { Digoxin, } \\
\text { amiodarone }\end{array}$ & \multirow{4}{*}{$\begin{array}{l}\text { ACE } \\
\text { inhibitors } \\
\text { Xamoterol, } \\
\beta \text { blocker } \\
\text { ? Any of } \\
\text { benefit } \\
\beta \text { Blocker, } \\
\text { Ca antagonist } \\
\text { Non-ACE inhibitor } \\
\text { vasodilator }\end{array}$} & & \\
\hline $\begin{array}{l}\text { Left ventricular diastolic } \\
\text { dysfunction }\end{array}$ & Diuretic & & & \multirow{3}{*}{$\begin{array}{l}\text { Aspirin or } \\
\text { warfarin } \\
\text { Aspirin or } \\
\text { warfarin } \\
?\end{array}$} \\
\hline Angina & Nitrate & & \multirow{2}{*}{$\begin{array}{l}\text { Surgery or PTCA, } \\
\text { xamoterol }\end{array}$} & \\
\hline $\begin{array}{l}\text { Mitral or aortic } \\
\text { regurgitation }\end{array}$ & $\begin{array}{l}\text { ACE Inhibitor, } \\
\text { diuretic, } \\
\text { surgery }\end{array}$ & & & \\
\hline $\begin{array}{l}\text { Mitral or aortic } \\
\text { stenosis }\end{array}$ & $\begin{array}{l}\text { Diuretic, } \\
\text { surgery }\end{array}$ & & $\beta$ Blocker & \multirow{4}{*}{$\begin{array}{l}\text { Warfarin for } \\
\text { mitral stenosis } \\
\text { Aspirin } \\
\text { (? warfarin) } \\
\text { Heparin } \\
\text { (if not receiving } \\
\text { antithrombotic) }\end{array}$} \\
\hline Elderly patients & $\begin{array}{l}\text { \Dose of ACE inhibitor } \\
\text { and diuretic }\end{array}$ & Digoxin & Xamoterol & \\
\hline $\begin{array}{l}\text { Acute pulmonary } \\
\text { oedema }\end{array}$ & $\begin{array}{l}\text { Diuretic, } \\
\text { oxygen, } \\
\text { diamorphine, } \\
\text { nitrate }\end{array}$ & \multirow{4}{*}{$\begin{array}{l}\text { لdose of } \\
\text { ACE inhibitor } \\
\text { Amiodarone }\end{array}$} & $\begin{array}{l}\text { Aminophylline, } \\
\text { salbutamol, } \\
\text { digoxin, } \\
\text { dopamine or dobutamine }\end{array}$ & \\
\hline Renal dysfunction & $\begin{array}{l}\downarrow \text { Hypotensive } \\
\text { drugs }\end{array}$ & & Check for NSAIDs & \\
\hline $\begin{array}{l}\text { Ventricular } \\
\text { arrhythmia }\end{array}$ & Optimise treatment & & \multirow[t]{2}{*}{$\begin{array}{l}\beta \text { Blocker, } \\
\text { ?magnesium }\end{array}$} & $\beta$ Blocker? \\
\hline $\begin{array}{l}\text { Cor pulmonale or right } \\
\text { heart failure }\end{array}$ & $\begin{array}{l}\text { Diuretic } \\
\text { (spironolactone), } \\
\text { oxygen }\end{array}$ & & & Warfarin \\
\hline
\end{tabular}

$\downarrow$ Decrease; LVSD, left ventricular systolic dysfunction; PTCA, percutaneous transluminal coronary angioplasty; NSAIDs, non-steroidal anti-inflammatory drugs.

surrogate methods should be used-that is, non-invasive testing. Haemodynamic measurements should not be used for routine testing.

The ideal drug or combination of treatments will depend on the desired goals (table 2). Thus for the mildly symptomatic 50 year old prognosis is usually the main issue, whereas for the patient with severe heart failure, even though the prognosis is very poor, treating symptoms is most important (figure). The ideal combination depends on the doses of the drugs used as well as the different components. The concept of the ideal combination should also exclude harmful or unnecessary drugs.

\section{Treatment of asymptomatic left} ventricular systolic dysfunction

The primary goal here is to reduce morbidity and improve prognosis. Angiotensin converting enzyme inhibitors reduce the risk of developing heart failure and possibly of reinfarction. When used early, although not

Relative importance of prognosis and symptoms in the management of patients with heart failure. In mild heart failure, symptoms are not prominent and improving survival is the primary therapeutic aim. In more severe heart failure relief of symptoms is of paramount importance even though the prognosis is poor.

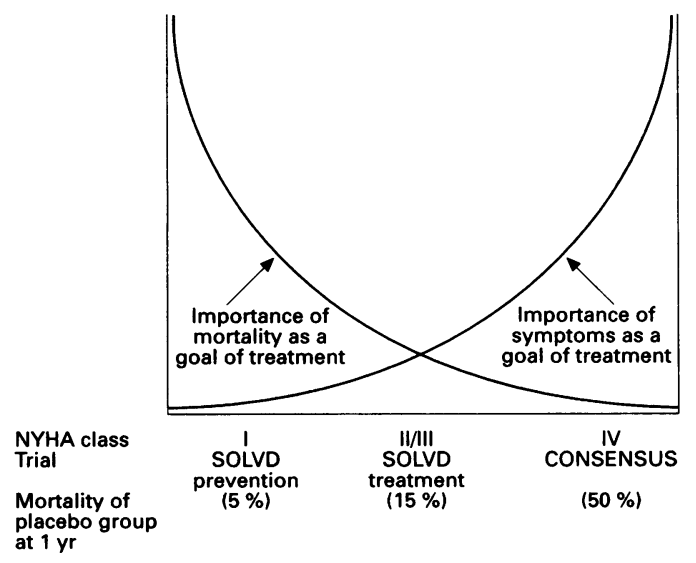

immediately, after a large myocardial infarction they can reduce mortality. ${ }^{15} 16$ Although the study of left ventricular dysfunction (SOLVD) prevention, which excluded patients who had had an infarct within the previous six months, did not show an effect on survival the trend was favourable. ${ }^{17}$ The studies that have shown benefit have used large doses of ACE inhibitors and this must be the recommended practice until data are available from studies, such as assessment of treatment with lisinopril and survival (ATLAS) and NETWORK, that will determine whether small doses are as effective as large ones.

$\beta$ Blockers exert similar relative prognostic benefits after myocardial infarction whether heart failure is present or not, but as heart failure indicates a poor prognosis the absolute benefit is greater when heart failure is present. ${ }^{18} \beta$ Blockers also reduce the risks of heart failure developing after a myocardial infarction, particularly in those studies where treatment with $\beta$ blockers was delayed. ${ }^{18} \beta$ Blockers reduce the risks of reinfarction and arrhythmias, which may account for their impact on survival. The effects of $\beta$ blockers on symptoms are controversial but side effects seem less troublesome in asymptomatic left ventricular systolic dysfunction than previously supposed.

Aspirin and warfarin reduce the likelihood of reinfarction or death in asymptomatic left ventricular systolic dysfunction due to ischaemic heart disease. ${ }^{19} 20$ Aspirin is the most convenient whereas warfarin is probably more effective, but more risky.

Unless a complicating factor exists such as hypertension, angina, or atrial fibrillation unresponsive to these treatments, vasodilator drugs, diuretics, and digoxin should be 
avoided. In patients who do not tolerate an ACE inhibitor there is no evidence that substitution with a vasodilator is of value. Calcium antagonists such as nifedipine may be harmful after a myocardial infarction, ${ }^{21}$ and the data on nitrates are scant. ${ }^{22}$ The physician should actively consider withdrawing calcium antagonists and class I antiarrhythmic drugs that have been shown to be harmful in (impending) heart failure. ${ }^{23}$

\section{Mild heart failure (New York Heart} Association (NYHA) class II) associated with left ventricular systolic dysfunction The goals of treatment are generally similar to those for the treatment of asymptomatic left ventricular systolic dysfunction although more attention must be paid to symptoms. Unless contraindicated, patients should receive a high dose of ACE inhibitor, ${ }^{62425}$ and this should be combined with a diuretic if there is peripheral oedema. For patients who cannot take an ACE inhibitor the combination of hydralazine and nitrates may offer some prognostic benefit although doubt has been cast on the analysis of these results. ${ }^{26}{ }^{27}$ In patients with mild symptoms ACE inhibitor monotherapy may be tried for two to three months before adding a diuretic. In those with more prominent symptoms a small dose of diuretic can be added at an earlier stage.

Frusemide or bumetanide are the diuretics of choice, as they exert smaller effects on glucose and urate metabolism and cause less hypokalaemia than thiazides. Thiazides may cause more unwanted hypotension and, due to their long duration of action, nocturia and syncope. Thiazides are ineffective if the glomerular filtration rate is low, a common finding in elderly patients.

Although diuretics are probably the single most effective agents for improving breathlessness and ankle swelling associated with heart failure they also cause considerable morbidity, such as lethargy, postural hypotension, metabolic disturbance, and urinary incontinence. Diuretics may also contribute to the mortality of heart failure by activating the renin-angiotensin-aldosterone and sympathetic nervous systems and causing electrolytic disturbances. The mortality in the SOLVD treatment group was about $35 \%^{24}$ and in the SOLVD prevention trial it was only $15 \% .{ }^{17}$ The obvious difference between the groups was the proportion receiving diuretics. Although the patients in the SOLVD treatment trial were more symptomatic the ejection fraction, one of the best prognostic indicators, was similar to that found in the less symptomatic patients in the prevention trial (25\% and $28 \%$ respectively). Diuretics should be used in low doses initially-for example, $20 \mathrm{mg} /$ day frusemide. Neutral endopeptidase inhibitors that enhance the diuretic effects of endogenous atrial natriuretic peptide but suppress the renin-angiotensin system are new diuretic alternatives in development. ${ }^{28}$

If the patient is immobile or has problems with incontinence or prostatic disease even small doses of diuretic may be troublesome and alternatives should be considered. The symptomatic benefits of digoxin in mild heart failure and sinus rhythm are modest ${ }^{29}$ and the effects on prognosis are unknown, but they are possibly deleterious. One promising development is xamoterol, a $\beta$-1-partial agonist, which exerts beneficial effects on all the main symptoms associated with mild heart failure. ${ }^{30}$ Although xamoterol increases mortality in patients with severe heart failure, ${ }^{31}$ at least when initiated abruptly in full doses, studies in mild heart failure have shown the opposite trend. ${ }^{30} \beta$ Blockers are also advocated by some for ischaemic heart failure and dilated cardiomyopathy, although more formal trials are awaited. ${ }^{32} 33$ A $\beta$ blocker or xamoterol offers better rate control of atrial fibrillation than digoxin. Xamoterol is especially useful as it controls exercise tachycardia and reduces the frequency and duration of pauses. ${ }^{34}$

Interestingly, the results for xamoterol in severe heart failure suggested that long acting (and therefore relatively high dose) ACE inhibitors were associated with a better prognosis than short acting agents, possibly by neutralising the deleterious effects of xamoterol..$^{35}$ Similarly, ACE inhibitors seem more effective in reducing mortality among patients treated with diuretics. This suggests that some of the prognostic benefit of ACE inhibitors may be due to their ability to neutralise an adverse effect of diuretics. ${ }^{17} 2425$

Myocardial reinfarction is a major cause of morbidity and death in patients with heart failure and aspirin and warfarin are both effective in preventing reinfarction according to studies of angina and myocardial infarction, although this has not been tested in heart failure. ${ }^{1920}$ Recently there have been concerns over the potential for aspirin to negate the haemodynamic, and possibly prognostic benefits of ACE inhibitors. ${ }^{36}$ These questions should be resolved by large studies such as the warfarin aspirin study of heart failure (WASH).

\section{Severe heart failure (NYHA class III or} IV) associated with left ventricular systolic dysfunction

The primary goals of treatment are to reduce symptoms and morbidity. Although the prognosis is poor, extending a miserable existence by a few months, if there is no hope of a definitive surgical intervention, is of secondary importance.

Fortunately, the optimal regimen for these patients improves symptoms and reduces morbidity and mortality, as ACE inhibitors and diuretics in partnership are the optimal treatment. ${ }^{2425}$ About $15 \%$ of patients are unsuitable for, or cannot tolerate, an ACE inhibitor. ${ }^{24}$ The combination of hydralazine and nitrate may be a useful alternative although the benefits on symptoms and morbidity are poorly substantiated, and their effect on prognosis is in doubt. ${ }^{27}$ The combination of hydralazine and nitrate is a complex regimen with many side effects and compliance is 
poor. Flosequinan promised to be an alternative simple regimen, but despite the fact that it proved consistently effective in relieving symptoms and improving quality of life in short-term studies, in long-term studies it increased mortality and admissions to hospital and has unfortunately been withdrawn.

In some centres it is considered unreasonable to put a patient on the waiting list for transplantation without a trial on a $\beta$ blocker. A recent large trial in patients with dilated cardiomyopathy suggested that $\beta$ blockers reduce morbidity although the effect on mortality was not significant. ${ }^{37}$ Until further information is available it seems wise to reserve $\beta$ blockers for patients with concomitant angina. For patients with atrial fibrillation and severe heart failure digoxin is the drug of choice. ${ }^{38}$

Antithrombotic strategies need to be considered as for mild heart failure.

Many patients with severe heart failure do not respond to ACE inhibitors and diuretics in conventional doses. The doses of either the diuretic or ACE inhibitor may be increased or a third agent may be added. The optimal dose of ACE inhibitor is unknown but there seems little to be gained by doses of $>20 \mathrm{mg}$ of enalapril twice daily although $50 \mathrm{mg}$ of captopril three times daily could be sub-optimal as it does not suppress angiotensin II throughout the day. ${ }^{39}{ }^{40}$ Reducing the dose of the ACE inhibitor may be necessary if severe renal dysfunction develops, but if this has occurred as a consequence of treatment then other options should be reviewed. ${ }^{41}$

A dose of frusemide of $>1 \mathrm{~g} /$ day is one successful alternative for controlling severe heart failure, and the use of diuretic combinations is another. Amiloride and triamterene increase the diuresis produced by loop diuretics alone and are often needed to prevent or correct hypokalaemia. As potassium rises this stimulates the secretion of aldosterone, which reduces the risk of dangerous hyperkalaemia but blunts the natriuretic activity of the diuretic. ${ }^{41}$ To combine a loop diuretic and an ACE inhibitor with spironolactone may be more effective but has a greater risk of hyperkalaemia. ${ }^{41}$ Thiazides, not exclusively metolazone, can exert a remarkable diuresis when combined with a loop diuretic. ${ }^{42}$ Hypokalaemia and the adverse metabolic profile of the thiazides are drawbacks. The best diuretic combination is unknown but amiloride or triamterene is the safest option for correcting hypokalaemia and the use of thiazides combined with modest doses of loop diuretics rather than very high doses of frusemide is becoming fashionable.

As an alternative or as well as diuretic combinations there are other options, such as an additional vasodilator, inotropic agent, or digoxin, which is both and a diuretic too. ${ }^{43}$ The evidence is now fairly convincing that digoxin does exert symptomatic benefit even in sinus rhythm in severe heart failure, ${ }^{38}$ but it may have adverse effects on morbidity and mortality. The use of vasodilators as well as an ACE inhibitor is unproved. ${ }^{22}$
Phosphodiesterase inhibitors are not generally available in an oral form. A large study of milrinone indicated that it made patients feel worse and reduced survival, ${ }^{44}$ but others have shown short-term improvements in symptoms that may be useful in treating very sick patients. ${ }^{45}$ A study with vesnarinone has identified that at low doses this drug may be effective without an adverse effect on mortality. ${ }^{46}$ As the effects of these drugs are enhanced during exercise, but the dose ranging studies were conducted at rest, the surrogate haemodynamic end point may have led to the use of excessive doses.

\section{Atrial fibrillation and heart failure}

The first decision is whether to cardiovert or just control the ventricular rate. Sinus rhythm producing a regular controlled heart rate and atrial transport is logically the best outcome, and should reduce the risk of emboli. Unfortunately most patients with pre-existing heart failure will relapse into atrial fibrillation within six months of cardioversion, and anaesthesia and electrical cardioversion are not without hazard. About $15 \%$ of patients can be cardioverted with amiodarone $(200 \mathrm{mg}$ three times daily. ${ }^{47}$ If amiodarone alone fails then electrical cardioversion and a maintenance dose of amiodarone is appropriate if atrial fibrillation is not longstanding and the left atrium not grossly dilated. If atrial fibrillation persists amiodarone should be withdrawn as less toxic drugs are available for the control of ventricular rate.

Heart rate can be controlled with a $\beta$ blocker or xamoterol ${ }^{35}$ in patients with mild heart failure or with digoxin in patients with more severe heart failure. Warfarin is better than aspirin for antithrombotic prophylaxis, ${ }^{48}$ although in elderly patients the risk to benefit ratio may favour aspirin.

\section{Diastolic heart failure}

The most important issue is to get the diagnosis right. Diastolic dysfunction is always present when systolic dysfunction is present. Isolated diastolic function is rare in young patients and its reputed high incidence in elderly patients may have more to do with poor diagnosis and undue faith in tests than real disease. None the less, heart failure due to amyloid or hypertrophic cardiomyopathy may present with only subtle abnormalities of systolic function. Diastolic failure may be due to impaired myocardial relaxation or due to infiltration of the myocardium or pericardium causing a constrictive pattern, commonly with fibrous collagen and rarely with amyloid.

Diuretics may be used to relieve oedema but as cardiac output and blood pressure are dependent on high filling pressures, excessive use of diuretics and vasodilators are contraindicated. $\beta$ Blockers impair myocardial relaxation but prolong diastole; their place in the treatment of diastolic heart failure is not proved. No specific drug treatment for the constrictive process exists, but surgery may 
help in pericardial disease. Digoxin should be avoided in amyloidosis and hypertrophic cardiomyopathy.

\section{Heart failure with angina}

The heart failure should be treated on its own merits. The ACE inhibitors do not usefully improve and may exacerbate angina in patients on high doses of a diuretic where the fall in blood pressure may be considerable. ${ }^{49}$ Nitrates are probably the best complement to diuretics, ACE inhibitors, and antithrombotic treatment in patients with heart failure and angina. Sublingual nitrates may be used if angina is infrequent. Once daily long acting nitrates may be used for more severe angina without inducing tolerance.

$\beta$ Blockers and xamoterol control exercise induced tachycardia and if gradually introduced may not worsen heart failure. Calcium antagonists should be reserved for those in whom nitrates and $\beta$ blockers have failed. Dihydropiridines are of limited efficacy, diltiazem increases mortality, and although verapamil may not increase mortality if often makes heart failure worse..$^{50}$

It is now possible to operate on patients with angina even if heart failure is severe. Intractable angina rather than prognosis is the indication for surgery as the evidence for prognosis is weak. Angioplasty may also relieve angina, although the mortality of the procedure may equal or surpass that of surgery and may not improve, or even worsen prognosis in patients with angina and heart failure.

\section{Heart failure with renal dysfunction}

If the patient has pre-existing renal dysfunction the dose of the ACE inhibitor should be reduced accordingly. If the ACE inhibitor exacerbates renal dysfunction first try to reduce the dose of diuretic and other hypotensive agents. Increasing arterial and renal perfusion pressure will often reverse renal dysfunction. ${ }^{41}$ Nephrotoxic agents such as non-steroidal anti-inflammatory drugs should be withdrawn.

\section{Heart failure with ventricular arrhythmias}

Ventricular arrhythmias are frequent in patients with heart failure and confer a poor prognosis. ${ }^{12}$ Implantable defibrillators do prolong life in patients with symptomatic arrhythmias, ${ }^{51}$ albeit for a limited period, indicating that an effective antiarrhythmic drug should improve prognosis. No study has shown a conclusive benefit from such drugs, but it is clear that class I antiarrhythmic drugs, even after pro-arrhythmia and lack of efficacy have been excluded, shorten life. ${ }^{23}$

The best plan is to optimise treatment with diuretics, ACE inhibitors, and potassium sparing diuretics. Potassium supplements are ineffective in correcting hypokalaemia. Whether magnesium supplements can correct arrhythmias is controversial.
At present no other treatment can be recommended but $\beta$ blockers and amiodarone may both be useful antiarrhythmic agents. ${ }^{11}$ Ambulatory monitoring seems more effective in selecting treatment than electrophysiological testing. ${ }^{52}$

Heart failure and primary valve disease Surgery is the best option for most patients but many survive for years with valve regurgitation and heart failure, although the risks of operation increase with the delay. The patient must decide whether to take the risk of dying from an operation to increase overall life expectancy. In patients with aortic stenosis diuretics and control of atrial fibrillation are the only options; surgery should be considered even in advanced cases.

\section{Heart failure in elderly patients}

There is little information on how best to treat those aged over 75, despite the fact that they constitute a large proportion of patients with heart failure. Elderly patients are more likely to have a false positive diagnosis of heart failure or if heart failure is present to have a less common cause such as thyrotoxicosis or aortic stenosis. Yet this is the group who are least likely to be investigated and most likely to have side effects from drugs, especially if not needed.

The evidence available suggests that in those aged 70 to 79 that ACE inhibitors have similar or greater prognostic benefits than in younger patients and that at least some symptomatic benefit is obtained. The incidence of side effects including hypotension, renal failure, and mesenteric ischaemia rise considerably among patients in their eighties and the balance of risk and benefit are unresolved. ${ }^{53} 54$ Diuretics are also often poorly tolerated and more likely to cause metabolic disturbances sureh as hyponatraemia, incontinence, and postural hypotension. Xamoterol may be a suitable alternative for some.

\section{Right heart failure}

Some patients show signs of predominantly right heart failure, leading to hepatic congestion and decreased aldosterone degradation. Such patients may respond well to spironolactone. Experimental models that suggest that spironolactone also has a specific effect on myocardial fibrosis need to be substantiated.

\section{Acute heart failure}

Pulmonary oedema, unlike chronic heart failure, responds to measures directed at improving haemodynamics. Intravenous diuretics and nitrates are the combination of choice. Oxygen should be given for hypoxia and diamorphine in small doses to relieve anxiety and breathlessness. If bronchospasm is prominent $250 \mathrm{mg}$ of intravenous aminophylline given over 15 minutes or nebulised salbutamol may be helpful. If rapid atrial fibrillation 
is present then a glycoside should be used, given intravenously or orally depending on the circumstances. There is no proved advantage to the use of ACE inhibitors when haemodynamics are unstable; if an adverse event occurs it may be impossible to reverse.

\section{Summary}

Good management of all patients with heart failure is complex. Fortunately most patients fall into only one or two categories, making management less daunting. Most patients with heart failure need treatment with loop diuretics and ACE inhibitors and for many these drugs, possibly combined with antithrombotic measures, are all that is needed for optimal treatment, but optimal treatment can only follow adequate diagnosis. This needs a partnership between the specialist and the family doctor, with ease of access to non-invasive investigations such as echocardiography.

1 Cleland JGF, ed. Recognition and management of heart failure. Science Press, 1994 (in press)

2 Cleland JGF. Ancillary diagnostic and therapeutic issues. Current Opinion in Cardiology 1992;7:408-15.

3 Cleland JGF, Oakley CM. Vascular tone in heart failure: the neuroendocrine-therapeutic-interface. $\mathrm{Br}$ Heart 1991;66:264-7.

4 Gheorghiade $\mathrm{M}$, Sueta CA, Adams KF, et al. Multicenter randomised trial of epoprostenol in patients with severe heart failure. $¥ \mathrm{Am}$ Coll Cardiol 1992;19:216A

5 Cohn JN, Johnson GR, Shabetai R, et al. Ejection fraction, peak oxygen consumption, cardiothoracic ratio, ventricupeak oxygen consumption, cardiothoracic ratio, ventricular arrthymias and plasma norepinephrine as determinants of prognosis in

6 Cohn JN, Johnson G, Ziesche S, et al. A comparison of enalapril with hydralazine-isosorbide dinitrate in the treatment of chronic congestive heart failure. $N$ Engl $\mathscr{f}$ Med 1991;325:303-10

7 Lewis GRJ. Lisinopril versus placebo in older congestive heart failure patients. Am $\underset{f}{ }$ Med 1899;85(suppl 3B): $48-54$

8 Cowley AJ, Wynne RD, Swami A, Birkhead J, Sene A, Hampton JR. A comparison of the effects of captopril and flosequinan in patients with severe heart failure. Cardiovasc Drugs Ther 1992;6:465-70

9 Flosequinan mortality. Drug Ther Bull 1993;31:47-8.

10 Swedberg K, Eneroth P, Kjekshus J, Wilhelmsen L. Hormones regulating cardiovascular function in patients with severe congestive heart failure and their relation to with severe congestive heart failure and

11 Cohn JN, Levine TB, Olivari MT, et al. Plasma norepinephrine as a guide to prognosis in patients with chronic congestive heart failure. $N$ Engl $\mathscr{f}$ Med 1984 311:819-23

12 Dargie HJ, Cleland JGF, Leckie BJ, Inglis CG, East BW, Ford I. Relation of arrhythmias and electrolyte abnormalities to survival in patients with severe chronic hear failure. Circulation 1987;75(suppl IV):IV-98.

13 Cody RJ, Torre S, Clark M, Pondolfino K. Age-related hemodynamic, renal, and hormonal differences among patients with congestive heart failure. Ann Intern Med 1989;149:1023-8.

14 Lerman A, Gibbons RJ, Rodeheffer RJ, et al. Circulating $\mathrm{N}$-terminal atrial natriuretic peptide as a marker for symptomless left ventricular dysfunction. Lancet 1993; 341:1105-9.

15 Pfeffer M, Braunwald E, Moye LA, et al. Effect of captopril on mortality and morbidity in patients with left ven tricular dysfunction after myocardial infarction. $N$ Engl $f$ Med 1992;327:669-77.

16 The Acute Infarction Ramipril Efficacy (AIRE) Investigators. Effect of ramipril on mortality and morbidity of survivors of acute myocardial infarction with clinical evidence of heart failure. Lancet 1993;342:821-8.

17 The SOLVD Investigators. Effect of enalapril on mortalit and the development of heart failure in asymptomatic patients with reduced left ventricular ejection fractions. N Engl f Med 1992;327:685-91.

18 Yusuf S, Peto R, Lewis J, et al. Beta blockade during and after myocardial infarction: an overview of the randomised trials. Prog Cardiovasc Dis 1985;27:335-71.

19 Smith $\mathrm{P}$, Arnesen $\mathrm{H}$, Holme I. The effect of warfarin on mortality and reinfarction afte

20 Antiplatelet Trialists Collaboration. Secondary prevention of vascular disease by prolonged antiplatelet treatment. of vascular disease by
21 Goldbourt, U, Behar S, Reicher-Ross H, Zion $M$ Mandelzweig L, Kaplinsky E, for the SPRINT Study Group. Early administration of nifedipine in suspected acute myocardial infarction. Arch Intern Med 1993 153:345-53.

22 Wieshammer S, Hetzel M, Hetzel J, Kochs M, Hombach $V$. Lack of effect of nitrates on exercise tolerance in patients with mild to moderate heart failure caused by coronary disease already treated with captopril. $\mathrm{Br}$ Hear f 1993;70:17-21.

23 CAST Study. Preliminary report: effect of encainide and flecainide on mortality in a randomized trial of arrhythmia suppression after myocardial infarction. $N$ Engl $₹ \mathrm{Med}$ 1989;321:406-11.

24 The SOLVD Investigators. Effect of enalapril on survival in patients with reduced left ventricular ejection fractions and congestive heart failure. $N$ Engl f Med 1991; 325:293-302

25 The CONSENSUS Trial Study Group. Effects of enalapril on mortality in severe congestive heart failure Results of the cooperative North Scandinavian enalapril survival study (CONSENSUS). N Engl $f$ Med 1987 316:1429-35.

26 Cohn JN, Archibald DG, Ziesche S, Franciosa JA Harston WE, Tristani FE, et al. Effect of vasodilato therapy on mortality in chronic congestive heart failure. Results of a Veterans Administration co-operative study. N Engl f Med 1986;314:1547-52.

27 Cohn JN. Statistical significance of Veterans Administration vasodilator heart failure trial results. $A m \mathcal{f}$ Cardiol 1990;66:1507-8.

28 Good J, Frost G, Jackson N, Watson S, Oakley C, Cleland J. Response to candoxatrilat in patients with severe heart failure. Eur Heart $₹$ 1992;13(suppl):241.

29 Digoxin Multi-Centre Research Group. Comparative effects of therapy with captopril and digoxin in patients with mild to moderate heart failure. $f A M A 1988$ 259:539-44.

30 The German and Austrian Xamoterol Study Group. Double-blind placebo-controlled comparison of digoxin and xamoterol in chromic heart failure. Lancet 1988;i:489-93.

31 Nicholas G, Oakley C, Pouleur H, Fousseau MF, Ryden $\mathrm{LE}$, Wellens $\mathrm{H}$, et al. Xamoterol in severe heart failure. Lancet 1990;336:1-6.

32 Waagstein F, Caidahl $\mathrm{K}$, Wallentin I, et al. Long-term $\beta$ blockade in dilated cardiomyopathy: effects of short- and long-term metoprolol treatment followed by withdrawal and readministration of metoprolol. Circulation and readminis

33 Woodley SL, Gilbert EM, Anderson JL, et al. $\beta$-Blockade with bucindolol in heart failure caused by ischemic versus idiopathic dilated cardiomyopathy. Circulation 1991;84: 2426-41

34 Ang EL, Chan WL, Cleland JGF, Moore D, Krikler S Alexander NDE, Oakley CM. Placebo controlled trial of xamoterol versus digoxin in chronic atrial fibrillation. $B$ Heart $\mathcal{F} 1990 ; 64: 256-60$

35 Pouleur H, Rousseau MF, Oakley CM, Ryden L. Difference in mortality between patients treated with captopril or enalapril in the xamoterol in severe heart failure study. Am $\mathcal{f}$ Cardiol 1991;68:71-4.

36 Hall D, Zeitler H, Rudolph W. Counteraction of the vasodilator effects of enalapril by aspirin in severe heart vailure. $₹ \mathrm{Am}$ Coll Cardiol 1992;20:1549-55.

37 The MDC Study Group. Metoprolol in dilated cardiomyopathy. A multicenter randomized placebomyopathy. A multicenter randomized place

38 Packer M, Gherrghiade M, Young JB, et al. Withdrawal of digoxin from patients with chronic heart failure treated with angiotensin-converting-enzyme inhibitors. $N$ Engl $\mathscr{f}$ Med 1993;329:1-7.

39 Cleland JGF, Dargie HJ, Ball SG, Gillen G, Hodsman GP, Morton JJ, et al. Effects of enalapril in heart failure: a double blind study of effects on exercise performance, renal function, hormones, and metabolic state. Br Heart $1985 ; 54: 305-12$

40 Cleland JGF, Dargie HJ, Hodsman GP, Ball SG, Robertson JIS, Morton JJ, et al. Captopril in heart failure: a double blind controlled trial. $\mathrm{Br}$ Heart $\mathcal{f}$ 1984;52:530-5.

41 Cleland JGF, ed. The clinician's guide to ACE-inhibition. Edinburgh: Churchill Livingstone, 1993.

42 Kiyingi A, Field MJ, Pawsey CC, Yiannikas J, Lawrence JR, Arter WJ. Metolazone in treatment of severe refractory congestive heart failure. Lancet 1990;335:29-31.

43 Good JM, Sbarouni E, Frost G, Meek J, Oakley CM Cleland JGF. Does digoxin facilitate the renal response to furosemide in chronic heart failure. $\mathcal{F} \mathrm{Am}$ Coll Cardio 1993;21:468A.

44 Packer $M$, Carver JR, Rodeheffer RJ, Ivanhoe RJ, DiBianco R, Zeldis SM, et al. Effect of oral milrinone on mortality in severe chronic heart failure. $N$ Engl $\mathcal{f} \mathrm{Med}$ 1991;325:1468-75.

45 DiBianco R, Shabetai R, Kostuk W, Moran J, Schlant RC Wright $\mathrm{R}$, et al. A comparison of oral milrinone, digoxin, and their combination in the treatment of patients with chronic heart failure. $N$ Engl f Med 1989;320:677-83.

46 Feldman AM, Bristow MR, Parmley WW, et al. Effects of vesnarinone on morbidity and mortality in patients with heart failure. $N$ Engl f Med 1993;329:149-55.

47 Gosselink ATM, Crijns HJGM, van Gelder IC, Hillige $H$ Wiesfeld ACP, Lie KI. Low-dose amiodarone for maintenance of sinus rhythm after cardioversion of atrial fibtenance of sinus rhythm after cardioversion or flutter. $¥ A M A 1992 ; 267: 3289-93$. 
48 Petersen P, Boysen G, Godtfredsen J, Andersen ED, Andersen B. Placebo-controlled, randomised trial of warfarin and aspirin for prevention of thromboembolic complications in chronic atrial fibrillation: the Copenhagen AFASAK study. Lancet 1989;1:175-9.

49 Cleland JGF, Henderson E, McLenachan J, Findlay I, Dargie HJ. Effect of captopril, an angiotensin converting enzyme inhibitor, in patients with heart failure and angina pectoris. F Am Coll Cardiol 1991;17: 733-9.

50 Goldstein RE, Boccuzzi, Cruess D, Nattel S, Friday K, Lenkei S, Nattel S, Rubison M. Diltiazem increases late Lenkei $S, N a t t e l$, Rubison $M$. Diltiazem increases late onset congestive heart failure in postinfarction patients 1991;83:52-60.

51 Levine JH, Mellits D, Baumgardner RA, Veltri EP, Mower $\mathrm{M}$, Grunwald L, et al. Predictors of first discharge and subsequent survival in patients with automatic implantable cardioverter-defibrillators. Circulation 1991 84:558-66.

52 The ESVEM Investigators. Determinants of predicted effcacy of antiarrhythmic drugs in the electrophysiologic study versus electrocardiographic monitoring trial. Circulation 1993;87:323-9.

53 O'Neill CJA, Bowes SG, Sullens CM, Royston JP, Hun WB, Denham MJ, et al. Evaluation of the safety of enalapril in the treatment of heart failure in the very old. Eur f Clin Pharmacol 1988;35:143-50.

54 O'Neill CJA, Charlett A, Dobbs RJ, Deshmukh AA, Bowes SG, Weller C, et al. Effect of captopril on functional, physiological and biochemical outcome criteria in aged heart failure. Br $\mathcal{F}$ Clin Pharmacol 1992;33:167-78. 